\title{
The Second Formation of Islamic Law: The Post-Mongol Context of the Ottoman Adoption of a School of Law
}

\author{
GUY BURAK
}

\section{Bobst Library, New York University}

In several public talks, the late art historian Oleg Grabar suggested a supplement to his classic study The Formation of Islamic Art, which focuses on monuments from Syria, North Africa, and Islamic Spain from the eighth to the tenth centuries. ${ }^{1}$ It would be entitled "The Second Formation of Islamic Art," and would concentrate on the art produced in the eastern Islamic lands in the thirteenth and fourteenth centuries, roughly the century and a half following the Mongol invasions of the thirteenth century. ${ }^{2}$ In the present article I suggest that Grabar's periodization may serve historians of Islamic law as well, and that the thirteenth-century Mongol invasions opened a new chapter, although for somewhat different reasons, in the history of Islamic lawindeed, they initiated a second formation of Islamic law in this region.

Dramatic as I believe this was, the nature of Islamic law and the change it underwent in the post-Mongol era throughout Central, South, and Western Asia has received remarkably little attention. Instead, the historiography of Islamic law (shari' $a$ ) in the period has tended to follow the lead of those historical sources that emphasize continuity in the nature of Islamic law from the preMongol period up to the legal reforms of the nineteenth century. Most significantly for the purpose of this article, the modern historiography tends to understand pre-nineteenth-century Islamic law as the realm of the jurists (it is occasionally described as "jurists" law"), who regulated the content of the

Acknowledgments: Many readers commented on many versions of this article. I would like to thank Bruce Grant, Adi Burak, Yigal Nizri, Nada Moumtaz, Jonathan Brown, Selma Zecevic, Michael Gilsenan, and the participants at the May 2012 Approaches to Islamic Law and Society workshop at New York University's Hagop Kevorkian Center. I am also grateful to the anonymous CSSH reviewers for detailed comments and suggestions and to Andrew Shryock for encouragement. I also thank the Islamic Legal Studies Program of Harvard Law School for the fellowship during which this article was substantially revised.

1 Oleg Grabar, The Formation of Islamic Art (New Haven: Yale University Press, 1973).

2 Cited in Persis Berlekamp, Wonder, Image, \& Cosmos in Medieval Islam (New Haven: Yale University Press, 2011), 1-2. 
law almost independently, not subject, at least in theory, to the ruling dynasty's intervention. Accordingly, the "state" or the "sovereign" (such as the caliph, the sultan, and members of the ruling elite) - concepts that have figured quite prominently in the historiography of legal reforms since the nineteenth centuryare mostly marginalized in the historiography of pre-nineteenth-century Islamic law in terms of their involvement in its articulation.

This article will call into question elements of these grand narratives of Islamic legal history, and offer a historiographical framework that can account for institutional and doctrinal developments that significantly changed the nature of Islamic law in the eastern Islamic lands in the postMongol period. Chronologically, I will focus on the era that begins with the thirteenth-century Mongol invasions and the incorporation of these lands into a Mongol-Chinggisid empire. It encompasses also the Mongol empire's successor states, including the major early modern Islamic empires, from roughly the thirteenth through the eighteenth centuries, but possibly even later.

The major development that captures the change that I will analyze is the emergence of a new relationship between the ruling dynasty and the Islamic or to be more precise, Sunni-school of law, in the sense of a philosophical or intellectual school. More specifically, I am interested in the implications of the different dynasties' adopting a particular Islamic school of law as their official state school. These adoptions, I argue, were not merely acts of patronage, or of following jurists of a specific school-they were active attempts by the ruling dynasty to regulate the school's structures, authorities, and doctrines.

This development was inextricably tied to the rise of the notion of dynastic law in the centuries following the Mongol conquest. Many, if not all of the ruling dynasties sought to establish their legitimacy, as well as that of certain administrative and institutional practices, on the basis of guiding principles and rules that they attributed to the dynasty's ancestors. ${ }^{3}$ Among these practices were those that enabled dynasties to shape the structures and doctrines of their adopted school, or in some cases, schools, of law. Most studies of Islamic law in the period have focused on the degree to which these dynastic rules and practices were compatible or reconcilable with Islamic law. I will approach these questions of compatibility and reconcilability from a different angle, by looking at the institutional (or perhaps even constitutional) dimensions of the relations between ruling dynasties, dynastic law, and the Sunni school of law. In a nutshell, most dynasties in the eastern Islamic lands in this period had to cope with tensions between their respective dynastic laws and the preMongol ideal of Islamic law (as jurists' law), and they tried to ease these

\footnotetext{
${ }^{3}$ I use the term "dynastic law" and not state or secular law because the dynasty and its ancestors are the most important source of legitimacy. The term also captures the significance of the dynasty within the broader state or government.
} 
tensions through various practices whose legitimacy was largely predicated on dynastic law.

I begin by examining the rise of the official school of law (madhhab, pl. madhahib) in the Ottoman Empire from the fifteenth through the eighteenth centuries. I then point to similarities and parallels in other parts of the eastern Islamic lands during that period. Historiographically, this comparison is at times difficult, for some early modern Islamic polities and legal systems are better studied than others. Nevertheless, it seems to me that there is enough data in the secondary literature (and in some published primary sources) to point to some commonalities that merit attention.

Finally, this article seeks to contribute to the growing literature on political thought in the post-Mongol period. As John Woods observed, great experimentation and innovation in political thought characterized this period, "a time in which standard Sunni theories were subjected to the Turko-Mongol influences." " In recent years, several studies have explored the new political concepts and worldviews that appeared during that period. Most notably, it is clear that the sultans, emperors, and dynasties were seen to be of central cosmic importance. ${ }^{5}$ The study of the relationship between the dynasty, the jurists, and the madhhab may cast light on some understudied dimensions of the discourse of sovereignty over the centuries after the Mongol invasions. Further, it may open up new avenues for examining the connections between the new "political cosmologies" of the post-Mongol period and the new perceptions of Islamic law.

\section{THE OTTOMAN CASE STUDY: AN OFFICIAL SCHOOL OF LAW}

In 1535, Ottoman troops led by Sultan Süleyman Kanuni conquered Baghdad from the Safavids. Soon after the conquest, as several chroniclers recount, the sultan visited the tomb of Abu Hanifa, the eighth-century eponymous founder of the Hanafi school, and ordered its reconstruction and purification, since the tomb had been desecrated by the presence of the heretic Safavids. Although the Ottomans reconstructed other tombs in the city, this gesture was of particular importance because it represented the connection between the Ottoman dynasty (and, more concretely, the sultan), the Hanafi school of law, and its eponym. ${ }^{6}$ This connection, however, predated this conquest of Baghdad;

4 John E. Woods, The Aqquyunlu: Clan, Confederation, Empire: A Study in 15th/9th Century Turko-Iranian Politics (Minneapolis: Bibliotheca Islamica, 1976), 5.

5 Hüseyin Y1lmaz, The Sultan and the Sultanate: Envisioning Rulership in the Age of Süleymān the Lawgiver (1520-1566) (PhD diss., Harvard University, 2004); Muzaffar Alam, The Language of Political Islam: India, 1200-1800 (Chicago: University of Chicago Press, 2004); Anne F. Broadbridge, Kingship and Ideology in the Islamic and Mongol Worlds (Cambridge: Cambridge University Press, 2008); A. Azfar Moin, The Millennial Sovereign: Sacred Kingship and Sainthood in Islam (New York: Columbia University Press, 2012).

${ }^{6}$ Nașūhüu's-Silāḥī (Mațrāḳçī), Beyān-l Menāzil-i Sefer-i 'Írākeyn-i Sultān Süleymān Hā̄n (Ankara: Türk Tarih Kurumu, 1976), 46b-61a; Celālzāde Muștafā (Koca Nişānc1), Ṭabakāat 
since at least the early fifteenth century the Ottoman dynasty had adopted a particular branch of the Hanafi school as its official state school. The Ottoman adoption of this legal school, one of the four in Sunni Islam, is well known among students of Islamic societies, and yet they have paid little attention to its significance within the long history of the relationship between Muslim sovereigns and the Sunni schools of law. With this in mind, following Rudolph Peters, I seek in what follows to further explore the question: "What does it mean to be an official school of law?"7

A brief survey of the history and functions of the Sunni schools of law in the pre-Ottoman period will clarify what was at stake. The pre-Ottoman, and more generally the pre-Mongol Sunni Islamic school of law was a loose social organization, whose main function was to regulate the legal interpretation of the divine revelation and to determine the authority of particular interpreters. Beginning in the late eighth and early ninth centuries, the opinions of the leading schools' premier authorities were preserved in a growing body of texts. These texts also served as pedagogical tools, contributing to the schools' coherence across time and space. ${ }^{8}$ During the late ninth and tenth centuries the Sunni school of law was increasingly becoming a body of the doctrines and opinions articulated by the eponymous founder and the jurists of subsequent generations; in effect, the madhhab emerged as a legal discourse around which a community of jurists galvanized.

Despite the consolidation of the legal schools around specific legal discourses and hermeneutic principles, there were differences of opinion at what Wael Hallaq calls the "microlevel" of the school. Over the centuries, the Sunni schools of law developed discursive conventions and other institutional practices to guide their followers through the different opinions of the schools, and to point out what opinions and doctrines were considered

ül-Memalīk ve Deracāt ül-Mesālik (Wiesbaden: Franz Steiner Verlag GMBH, 1981), 258b-59a; Eyyûbî, Menâkib-i Sultan Süleyman (Risâle-i Pâdişâh-nâme) (Ankara: Kültür Bakanlığı, 1991), 88; İbrahim Peçevi, Tarih-i Peçevi (Istanbul: Matbaa-i Âmire, 1865-1867), 1: 184-85.

Rudolph Peters, "What Does It Mean to Be an Official Madhhab? Hanafism and the Ottoman Empire," in Peri Baerman, Rudolph Peters, and Frank E. Vogel, eds., The Islamic School of Law: Evolution, Devolution, and Progress (Cambridge: Islamic Legal Studies Program, Harvard Law School, distributed by Harvard University Press, 2005), 147-58.

${ }^{8}$ The literature on the formation of the schools of law is vast. Among the most important works on this issue are: Christopher Melchert, The Formation of the Sunni Schools of Law, 9th-10th Centuries CE (Leiden: Brill, 1997); Jonathan E. Brockopp, Early Maliki Law: Ibn 'Abd al-Hakam and His Major Compendium of Jurisprudence (Leiden: Brill, 2000); Wael B. Hallaq, Authority, Continuity and Change in Islamic Law (New York: Cambridge University Press, 2001); Nimrod Hurvitz, The Formation of Hanbalism: Piety into Power (London: RouteledgeCurzon, 2002); Nurit Tsafrir, The History of an Islamic School of Law: The Early Spread of Hanafism, (Cambridge: Islamic Legal Studies Program, Harvard Law School, distributed by Harvard University Press, 2004); Ahmed El Shamsy, From Tradition to Law: The Origins and Early Development of the Shafi ${ }^{\circ} \mathrm{i}$ School of Law in Ninth-Century Egypt (PhD diss., Harvard University, 2009). 
more authoritative. Many of the less authoritative, or minority opinions were preserved in the schools' texts and manuals. ${ }^{9}$

For our purposes here, it is important to stress that, doctrinally, neither the schools' evolution nor the regulation of their jurisprudential content were statesponsored. This is not to say that states and sovereigns did not contribute to dissemination of the schools by extending support, employment, and patronage to specific jurists, or did not shape doctrine in practice. As early as the seventh and eighth centuries, the Umayyad (661-750) and the 'Abbasid (750-1258) dynasties supported eminent jurists and appointed jurists to different positions in their realms. $^{10}$

In other cases rulers and sovereigns, while not intervening directly in the content of the law, adopted a school, or sometimes several, to be followed in their domains. In the Ayyubid and the Mamluk sultanates, for example, it was fairly common for the sultan to be a follower of the Shafi'i school of law, the most popular school in Egypt at that time. ${ }^{11}$ Furthermore, in the Mamluk sultanate, during the reign of Sultan al-Zahir Baybars (d. 1277), the state constituted a legal system in which all four schools were represented and specific cases were directed to judges of different schools. ${ }^{12}$ Although the Mamluk state regulated the adjudication procedures of cases dealing with specific issues, doctrinally it did not intervene in the different schools' structures or authorities, or the content of their laws, and it accepted the opinions of eminent jurists as to what the preponderant opinion of their respective school was. Moreover, although the Mamluk, like many contemporary and early Islamic dynasties, employed jurists, for the most part there was no institutionally identifiable group of jurists affiliated with the ruling dynasty. ${ }^{13}$ In Sherman Jackson's words, "The idea, thus, of state sovereignty entailing the exclusive right to determine what is and what is not law, or even what is and

9 Hallaq, Authority, 121-65. Eyyup Said Kaya, "Continuity and Change in Islamic Law: The Concept of Madhhab and the Dimensions of Legal Disagreement in Hanafi Scholarship of the Tenth Century," in Peri Baerman, Rudolph Peters, and Frank E. Vogel, eds., The Islamic School of Law: Evolution, Devolution, and Progress (Cambridge: Islamic Legal Studies Program, Harvard Law School, 2005), 26-40.

10 For example, Steven C. Judd, "Al-Awzā'ī and Sufyān al-Thawrī: The Umayyad Madhhab?" The Islamic School of Law: Evolution, Devolution, and Progress (Cambridge: Islamic Legal Studies Program, Harvard Law School, 2005), 10-25; Tsafrir, History of an Islamic School of Law.

${ }_{11}$ Sherman Jackson, Islamic Law and the State: The Constitutional Jurisprudence of Shihäb al-Dìn al-Qarafì (Leiden and New York: Brill, 1996), 53-56.

12 Yossef Rapoport, "Legal Diversity in the Age of Taqlid: The Four Chief Qadis under the Mamluks," Islamic Law and Society 10, 2 (2003): 210-28.

13 See, for example, Jonathan Porter Berkey, The Transmission of Knowledge in Medieval Cairo: A Social History of Islamic Education (Princeton: Princeton University Press, 1992); Michael Chamberlain, Knowledge and Social Practice in Medieval Damascus, 1190-1350 (Cambridge: Cambridge University Press, 1994); Daphna Ephrat, A Learned Society in a Period of Transition: The Sunni "Ulama” of Eleventh-Century Baghdad (Albany: State University of New York Press, 2000). 
what is not an acceptable legal interpretation, is at best, in the context of classical Islam, a very violent one."14

The fifteenth-century Ottoman adoption of a branch of the Hanafi school was a marked divergence from the practice of earlier centuries, for it entailed an active adaptation of the school. Institutionally, this change was both reflected in and enabled by the development of an imperial learned hierarchy with fairly standardized career and training tracks. Four interrelated aspects of this hierarchy's development merit our special attention: (1) the emergence of the institution of the state-appointed jurisconsult (mufti); (2) the rise of an imperial educational system; (3) the emergence of an imperial jurisprudential canon; and (4) the systematic reconstruction and recording of the school's genealogy. While modern historians have studied institutional and administrative dimensions of this important and innovative development in some detail, ${ }^{15}$ my focus here- the doctrinal implications of an imperial learned hierarchy_remains understudied. ${ }^{16}$

In classical Sunni jurisprudence, a mufti is a Muslim authority who dispenses his opinion (fatwa) in response to questions posed to him on religious and legal issues. (In some cases, since women could and did serve as muftis, to her). The mufti played a significant role in developing and regulating the doctrine of the Sunni school of law, since he was often permitted to exercise his independent discretion to derive new rules (ijtiha $\bar{a}$ ), and was expected to guide the school's less-competent followers and to instruct judges when they encountered cases not explicitly addressed in the legal literature. ${ }^{17}$

Central to my argument here is the fact that muftis, unlike judges (qadis), were not for the most part appointed by the leader of the Muslim community (i.e., the imam, most commonly understood as the sovereign), but rather were scholars independent of the dynast/sovereign. In the Mamluk sultanate in fourteenth and fifteenth centuries, for example, every jurist whose teacher granted him a permit to teach law and issue legal opinions (ijāzat al-tadrīs wa-l-iftā') was considered a mufti. ${ }^{18}$ In short, the production of muftis and the transmission

14 Jackson, Islamic Law, xv. See also Baber Johansen, "Secular and Religious Elements in Hanafite Law: Function and Limits of the Absolute Character of Government Authority," in E. Gellner and J. C. Vatin, eds., Islam et Politique au Maghreb (Paris: Editions du CNRS, 1981), 281-303.

15 Richard C. Repp, The Müfti of Istanbul: A Study in the Development of the Ottoman Learned Hierarchy (London: Ithaca Press, 1986); Abdurrahman Atcil, The Formation of the Ottoman Learned Class and Legal Scholarship (1300-1600) (PhD diss., University of Chicago, 2010).

16 There are important exceptions: Colin Imber, Ebu's-Su 'ud: The Islamic Legal Tradition (Stanford: Stanford University Press, 1997); Rudolph Peters, "What Does It Mean."

17 Much has been written on muftis. For example: Muhammad Khalid Masud, Brinkley Messick, and David S. Powers, eds., Islamic Legal Interpretation: Muftis and Their Fatwas, (Cambridge: Harvard University Press, 1996); Norman Calder, "al-Nawawi's Typology of Muftis and Its Significance for a General Theory of Islamic Law," Islamic Law and Society 3, 2 (1996): 137-64; Wael B. Hallaq, "From Fatwas to Furu': Growth and Change in Islamic Substantive Law," Islamic Law and Society 1, 1 (1994): 29-65; Brinkley Messick, "The Mufti, the Text and the World: Legal Interpretation in Yemen," Man 12, 1 (1986): 102-19; Hallaq, Authority.

18 This was also true in the Arab lands of the Ottoman Empire in later centuries. 
of their authority were independent from the state. ${ }^{19}$ The Ottoman practice was different from this classical understanding of the muftiship: from the early decades of the fifteenth century, as part of the development of an imperial learned hierarchy, the Ottoman dynasty began to appoint muftis, and by the mid-sixteenth century the chief imperial mufti (şeyhülislam), the highest-ranking state-appointed mufti, presided over the imperial learned hierarchy. Mufti appointments were not merely state patronage, but were also, as opponents of such appointments observed, an important means to specify particular opinions within the Hanafi school of law that jurists affiliated with the Ottoman dynasty and its learned hierarchy were to apply. ${ }^{20}$

The emergence of the hierarchy was accompanied by the establishment of an educational system - often labeled in modern scholarship as the imperial medrese system - with standardized career and training tracks. From the second third of the fifteenth century onward, and especially after the conquest of Constantinople/Istanbul, the Ottoman dynasty gradually established a network of imperial state-sponsored learning institutions across its domains. At least from the sixteenth century, but probably earlier, the foundation of these institutions marked, in Ottoman self-perception, the rise of the new imperial capital, and the Ottoman domains in general, as an important scholarly center in the Sunni Hanafi world. In the words of the sixteenth-century Ottoman chronicler Mustafa 'Ali, the Ottoman realms became "a fountain of wisdoms and sciences." 21 Increasingly, graduation from the imperial educational system became an important and at times indispensable prerequisite for obtaining an official judicial appointment and other positions in the state bureaucracy. This educational background was particularly important in the context of the empire's expansion over the course of the sixteenth century, as it incorporated other well-established learning centers and scholarly traditions in the Arab Middle East. In other words, the imperial educational system helped both the Ottoman dynasty and the jurists affiliated with it to cement their mutual connection. ${ }^{22}$

To be sure, earlier Islamic sovereigns and dynasties had been interested in overseeing the administration of learning institutions and their endowments, but the Ottoman hierarchy functioned, doctrinally, in a different manner. This

19 Devin Stewart, “The Doctorate of Islamic Law in Mamluk Egypt and Syria," in Joseph E. Lowry, Devin J. Stewart, and Shawkat M. Toorawa, eds., Law and Education in Medieval Islam: Studies in Memory of Professor George Makdisi (Cambridge: E.J.W. Gibb Memorial Trust, 2004), 45-90.

${ }^{20}$ Guy Burak, The Abu Hanifah of His Time: Islamic Law, Jurisprudential Authority and Empire in the Ottoman Domains (PhD diss., New York University, 2012), 43-114.

21 Mustafa b. Ahmed 'Ali, Künh ül-ahbâr (Istanbul: Darü't-Tiba'âti'l- '̂̂mîre, 1860-1861), vol. 1: 37. According to Mustafa 'Ali, this trend continued under Mehmet II's successors, Beyazid II and Selim I, the latter after the conquest of Greater Syria and Egypt brought scholars, poets, and jurists from these lands to the capital (ibid.).

${ }^{22}$ Repp, Müfti of Istanbul; Atcil, Formation of the Ottoman Learned Class; Burak, Abu Hanifah. 
shift was expressed in two sixteenth-century imperial, sultanic edicts issued during the reign of Süleyman Kanuni: in an edict of 1556 the sultan specified the texts that students of the imperial educational system were to study, and at around the same time, in an imperial legal code, the sultan prescribed the order in which these texts were to be studied within the system. ${ }^{23}$ From the midsixteenth century, as I have shown elsewhere, the authority to determine what texts should be consulted was conferred on the chief imperial mufti, who served, for that purpose, as an extension of the sultan. ${ }^{24}$ By specifying an imperial jurisprudential canon, the Ottoman sultans, and more generally the dynasty, sought to point to specific texts and opinions within the Hanafi school that members of the imperial hierarchy were to consult and teach.

In addition, the dynasty used its hierarchy to enforce certain minority opinions within the Hanafi school. Consider, for example, the following anecdote recorded by the eminent sixteenth-century chief imperial jurisconsult Ebu's-Su'ud Efendi in his biography: "In certain cases he [Ebu's-Su'ud] followed the path of [independent] judgment $\left(r a^{\prime} y\right)$. Then he took counsel with Sultan Süleyman ... on whether he could give fatwas according to what he saw fit, and to whichever he preferred of the solutions which occurred to him. A decree was issued accordingly." 25 Put differently, the chief mufti needed the sultan's edict, and approval, to rule according to a minority opinion within the school.

The dynasty's attempt to shape the structure of the Hanafi madhhab led high-ranking sixteenth- and seventeenth-century members of the hierarchy, such as 'Ali Çelebi Kinalızade (d. 1571) and Mahmud Kefevi (d. 1582), to document the intellectual genealogy (tabaqāt) of the imperial learned hierarchy within the legal school. These genealogies linked the school's founder, Abu Hanifa, to members of the hierarchy by reconstructing chains of transmission of jurisprudential knowledge and authority. By recording the history of the school's hierarchy, the authors excluded other scholarly and jurisprudential traditions within the madhhab that existed both across the empire and in other parts of the Islamic world, mostly in South and Central Asia. For example, the genealogies excluded most of the Hanafi jurists who operated throughout the Arab provinces of the empire from the second half of the fifteenth century onward, unless they authored texts that were incorporated into the aforementioned imperial jurisprudential canon. In addition to reconstructing chains of transmission of knowledge and authority within the school, these works were intended to point to the authoritative genealogies of specific

\footnotetext{
${ }^{23}$ Shahab Ahmed and Nenad Filipovic, "The Sultan's Syllabus: A Curriculum for the Ottoman Imperial Medreses Prescribed in a Fermān of Qānūnī Süleymān, Dated 973 (1565)," Studia Islamica 98/99 (2004): 183-218; Ahmed Akgündüz, ed., Osmanli Kanunnameleri ve Hukukî Tahlilleri (Istanbul: Fey Vakfi Yayınları, 1992), vol. 4: 662-64.

${ }^{24}$ Burak, Abu Hanifah, 244-45.

25 Imber, Ebu's-Su'ud, 106-10. See also Peters, "What Does It Mean," 148-49.
} 
legal arguments and doctrines within the Hanafi madhhab, which members of the hierarchy were to follow in their rulings and writings. ${ }^{26}$

All these institutional and doctrinal developments reveal the important role the sultan and the Ottoman dynasty played in regulating the doctrines within the Hanafi school of law. As several studies of the emergence of the Ottoman imperial learned hierarchy have shown, its formation was, to a considerable extent, the product of sultanic edicts and regulations, even though these edicts gained the support of many jurists who were affiliated with the Ottoman enterprise. ${ }^{27}$ And, as we have seen, following the sultan's edict, the opinions of the chief mufti became enforceable within the imperial legal system.

These sultanic edicts, regulations, and legal codes were part of what I refer to throughout this article as the Ottoman dynastic law (kanun). Multiple studies have been devoted to the nature of the Ottoman kanun over the decades. ${ }^{28}$ For our purpose here, suffice it to say that kanun came to denote various administrative and institutional practices. Although these were not always codified in the form of imperial legal codes and were constantly negotiated and reconfigured, kanun as a legal discourse was instrumental in legitimizing them. ${ }^{29}$ This legal corpus was dynastic in the sense that it was issued by, or in the name of, the sultan and the Ottoman dynasty, as the titles of some of the extant legal codes and edicts suggest. This is a key issue that I will discuss presently. Ottoman jurists struggled, as have modern scholars, to define the relationship between certain perceptions of Islamic law and the Ottoman kanun. Many scholars both Ottoman and modern have observed clear tensions between these legal discourses, each of which has different epistemological and

\footnotetext{
26 For a discussion of this body of genealogies, see Burak, Abu Hanifah, 115-215. In addition to these genealogies, a sizable corpus of biographical dictionaries emerged that were devoted to senior members of the imperial learned hierarchy. The founder of this genre was the sixteenth-century jurist and member of the hierarchy, Ahmed b. Mustafa Taşköprüzade (d. 1561). See Ahmed b. Mustafa Taşköprüzade, al-Shaqa'iq al-nu 'maniyya fi 'ulama' al-dawla al- 'Uthmaniyya (Beirut: Dār al-Kitāb al-'Arabī, 1975).

27 For example: Repp, Müfti of Istanbul; Atcil, Formation of the Ottoman Learned Class; Burak, Abu Hanifah.

${ }^{28}$ For example: Halil Inalcik, s.v. "Kanun"; and Imber, Ebu's-Su'ud; F. Babinger, s.v. "Nishandji," both in Encyclopedia of Islam (2d ed.), http://referenceworks.brillonline.com/ browse/encyclopaedia-of-islam-2; Uriel Heyd, Studies in Old Ottoman Criminal Law (Oxford: Clarendon Press, 1973); Molly Greene, A Shared World: Christians and Muslims in the Early Modern Mediterranean (Princeton: Princeton University Press, 2000), 27-32; Dror Ze'evi, Producing Desire: Changing Sexual Discourse in the Ottoman Middle East, 1500-1900 (Berkeley: University of California Press, 2006), 50; Snjezana Buzov, The Lawgiver and His Lawmakers: The Role of Legal Discourse in the Change of Ottoman Imperial Culture (PhD diss., University of Chicago, 2005); Timothy J. Fitzgerald, Ottoman Methods of Conquest: Legal Imperialism and the City of Aleppo, 1480-1570 (PhD diss., Harvard University, 2008), 188-95.

29 Başak Tuğ, Politics of Honor: The Institutional and Social Frontiers of "Illicit" Sex in Mid-Eighteenth-Century Ottoman Anatolia (PhD diss., New York University, 2009), 40-96; Cornell H. Fleischer, Bureaucrat and Intellectual in the Ottoman Empire: The Historian Mustafa Âli (1541-1600) (Princeton: Princeton University Press, 1986), 191-200.
} 
historical points of reference, and they have considered kanun and shari ' $a$ to be separate legal-political discourses that were not fully compatible. This incompatibility, so the argument goes, had to be resolved or reconciled. ${ }^{30}$

Most studies of the incompatibility and reconciliation of dynastic law and shari ' $a$, however, have tended to examine them by focusing on specific legal arguments or rules. If the sultan permitted, for example, the construction of new churches and synagogues, certain jurists and modern scholars may have considered his edict to contradict the tenets of Islamic law; on the other hand, if certain jurists succeeded in establishing that certain practices were permissible based on arguments they found in the Hanafi jurisprudential tradition, then these practices may have been considered licit according to Islamic law. Yet this approach fails to account for other dimensions of the relationship between Islamic and dynastic law, and seems to assume a very specific form of reconciliation of the two discourses. If we look at the relationship between dynastic and Islamic law from the perspective of the Islamic school of law, the madhhab, this very much complicates our understanding of reconciliation.

We have seen that the Ottoman adoption of the Hanafi school of law, and the privileged status granted to certain opinions and doctrines out of a broader range of opinions within the school, were predicated on dynastic law. Seen from this perspective, institutionally speaking, dynastic law and Islamic law were unequal within the imperial learned hierarchy and legal system. This point is particularly clear in moments of controversy among jurists over certain imperial practices. Consider the following example: In the fifteenth and sixteenth centuries, the practice of cash endowments (waqf al-nuqūd) stood at the center of a heated debate between leading members of the learned hierarchy. The idea behind the Ottoman innovation of cash endowments was to establish a trust with money, the interest from which might be used for charitable ends or, at times, be paid to the trust's founder. Since the Qur'an explicitly forbids interest, and because the practice had been vehemently condemned by Hanafi jurists of earlier centuries, serious efforts were required to justify this practice. In the sixteenth century, some jurists, even within the ranks of the imperial learned hierarchy, opposed it, while other leading jurists supported it. Their specific legal arguments need not detain us here, but it is clear that given the diversity of opinions within the Hanafi

\footnotetext{
30 The eminent sixteenth-century chief mufti Ebû's-Su 'ûd Efendi (d. 1574) is often seen to have been an important contributor to the "reconciliation" of dynastic and Islamic law in the Ottoman context. See, for example, Cornell H. Fleischer, "The Lawgiver as Messiah: The Making of Imperial Image in the Reign of Süleyman," in Gilles Veinstein, ed., Soliman le Magnifique et son temps, Galeries Nationales du Grend Palais, 7-10 March 1990 (Paris: Documentation française, 1992), 171-72; Y1lmaz, Sultan and the Sultanate, 74; Buzov, Lawgiver and His Lawmakers. Some scholars, however, have questioned the extent to which Ebû's-Su'ûd succeeded in attaining this goal. Imber, Ebu's-Su 'ud.
} 
school, the implementation of the opinion of the jurists supporting the practice was facilitated by the subsequent endorsement of that opinion by the Ottoman dynasty and its learned hierarchy. ${ }^{31}$

This is not to deny that there were disagreements between Ottoman sultans and members of the hierarchy, and indeed Ottoman chronicles are sprinkled with them. When the Ottoman sultan Osman II (r. 1618-1622) asked the chief mufti Es'ad Efendi (d. 1625) whether it would be lawful for him to execute his younger brother in order to ensure that potential competitors would not ascend the throne while he was at the front, Es' ad Efendi rejected his request. ${ }^{32}$ In another instance, the chief mufti argued that it was God and not the sultan who had appointed him to the senior position. ${ }^{33}$ Nevertheless, these disputes did not undermine the general legal, indeed constitutional, framework through which the sultan and the dynasty intervened in regulating the learned hierarchy's career and training tracks, the appointment of jurists and muftis, and, perhaps most importantly, the structure of the specific branch within the Hanafi madhhab that they adopted.

LOOKING EAST: THE OTTOMAN CASE IN COMPARATIVE PERSPECTIVE

Among the legal systems of the early modern Muslim world, the Ottoman legal system is the best studied. This may explain the central place it occupies in many accounts of Islamic legal history. Here I will expand the scope of inquiry and suggest that the history of the Ottoman legal system and learned hierarchy should be situated within the broader context of the eastern Islamic lands of that period. To this end, I will point to some key issues that figure in the modern scholarship of other, roughly contemporary polities (and, to a lesser extent, in primary sources produced throughout the eastern Islamic lands), and that bear significant similarities to the Ottoman case and its historiography. I am encouraged to pursue this line of inquiry by the fact that the study of the eastern Islamic lands in the post-Mongol period as a somewhat coherent unit has proven illuminating regarding many other topics, such as political thought, mysticism, and art and architecture (as indicated by Oleg Grabar's comment cited at the start of this paper). ${ }^{34}$

My intention is not to obscure the substantial differences between the different polities, such as in their size and political organization, and the

31 Jon E. Mandaville, "Usurious Piety: The Cash Waqf Controversy in the Ottoman Empire," International Journal of Middle Eastern Studies 10, 3 (1979): 289-308.

32 Baki Tezcan, "The Ottoman Mevali as 'Lords of the Law,"' Journal of Islamic Studies 20, 3 (2009): 404-6. See also Tezcan's, "Some Thoughts on the Politics of Early Modern Ottoman Science," in Donald Quataert and Baki Tezcan, eds., Beyond Dominant Paradigms in Ottoman and Middle Eastern/North African Studies (Istanbul: Center for Islamic Studies [ISAM], 2010), 135-56.

33 Burak, Abu Hanifah, 83.

34 For example: Nicola Di Cosmo, Allen J. Frank, and Peter B. Golden, The Cambridge History of Inner Asia: The Chinggisid Age (Cambridge: Cambridge University Press, 2009). 
social, ethnic, and denominational composition of their populations. Nor will I try to produce a comprehensive, comparative account of their differences and similarities, which would be overly ambitious for this short paper. Nor am I implying that the notions of law and sovereignty that concern us here were the only source of political inspiration drawn upon by Muslim dynasts and emperors across the eastern Islamic lands. I also do not mean to suggest that the discourses and ideas I trace here were always the most dominant ones throughout the region during this period - in most of these polities one finds multiple and at times contradictory discourses and ideals of sovereignty, kingship, and law. For example, in the fifteenth and sixteenth centuries, Ottoman sultans participated in Byzantine, Mamluk, and Mediterranean discourses of sovereignty and kingship, ${ }^{35}$ while the Mughal dynasty adopted many practices and discourses of kingship that prevailed across the subcontinent and beyond. ${ }^{36}$

My objective is to draw attention to the post-Mongol circulation of specific discourses and views concerning the relationship between dynastic and Islamic (Sunni) law across the eastern Islamic lands. The particular structure and discourse of authority of the Sunni school of law (and, more specifically, the Hanafi school of law) led me to focus on the Sunni dynasties. Nonetheless, much of what I will say can be also applied to Safavid Iran, the major Shi'i counterpart of the Ottomans. ${ }^{37}$

Methodologically, any comparison of the Sunni polities faces several challenges. First, again, there are gaps in the modern historiography of these polities. Second, there is much variation in the amount and nature of the primary sources from different parts of the eastern Islamic lands. For example, within the Hanafi school of law from the Ottoman lands we have a sizable corpus of biographical dictionaries dedicated to senior members of the imperial learned hierarchy, as well as several works that document the hierarchy's intellectual genealogies, but to my knowledge, none of the region's other scholarly circles produced such works. These gaps raise two fundamental questions: How should one treat the missing parts of the puzzle? And what is their relationship to the parts that we do have?

While I do not wish to downplay the challenges these gaps pose to any comparative account, I think that a comparative approach offers ways to bridge them, since the parts of the puzzle we possess indicate important

35 Emire Cihan Muslu, Ottoman-Mamluk Relations: Diplomacy and Perceptions (PhD diss., Harvard University, 2007); Gülrü Necipoğlu, "Süleyman the Magnificent and the Representation of Power in the Context of Ottoman-Hapsburg-Papal Rivalry," Art Bulletin 71, 3 (1989): 401-27.

${ }^{36}$ Lisa Balabanlilar, Imperial Identity in the Mughal Empire: Memory and Dynastic Politics in Early Modern South and Central Asia (New York: I. B. Tauris, 2012); A. Azfar Moin, Millennial Sovereign.

37 See Rula Jurdi Abisaab, Converting Persia: Religion and Power in the Safavid Empire (New York: I. B. Tauris, 2004); Devin J. Stewart, "The First Shaykh al-Islām of the Safavid Capital of Qavin," Journal of the American Oriental Society 116, 3 (1996): 387-405. 
similarities and shared patterns. These similarities, I contend, also permit us to extrapolate, albeit cautiously and tentatively, from the missing parts. The historiographical move I am suggesting, then, is bi-directional: On one hand, I suggest that the Ottoman adoption of a particular branch within the Hanafi school should be studied as part of a legal culture shared by polities and dynasties throughout the continent, despite their particularities. On the other, I use the Ottoman case to contextualize and explain similar administrative and legal practices found in other polities across Central and South Asia. To be more concrete, I will examine two practices that recur in different contexts across the eastern Islamic lands throughout the post-Mongol period (as well as in the modern historiography), which are central to my understanding of the Ottoman adoption and development of an official school of law: the appointment of muftis by the ruling dynasty, and the imperial canonization of jurisprudential texts. I am especially interested in investigating these developments as the outcome of the rise of dynastic law. ${ }^{38}$

The most striking pattern is the rise of the dynasty-appointed muftiship throughout the region. As early as the first decades of the fifteenth century, the Timurid ruler Shahrukh (d. 1447) appointed a shaykh al-islam for his domains. This office, which was held by members of two families, the descendants of Burhan al-Din al-Marghinani and Sa'd al-Din al-Taftazani, was intended to oversee all the juridical activity throughout the Timurid lands. ${ }^{39}$ Interestingly enough, the appointment of the first Timurid shaykh al-islam parallels similar developments in the Ottoman lands. Roughly around this time, the Ottoman sultan Murad II appointed Molla Şemseddin Fenari (d. 1431) to the newly created office of the chief mufti of the Ottoman lands, the şeyhülislam. ${ }^{40}$

A century later, around 1514, the itinerant jurist and chronicler Fazl Allah b. Ruzbahan (d. 1519) wrote a treatise in which he advised the new Özbek khan as to how to conduct the affairs of his state. In the chapter on the administration of the religious and judicial offices, the jurist advises the khan to appoint a chief jurisprudential authority, a shaykh al-islam: "When the sultan ( $p \bar{a} d \bar{\imath} s h \bar{a} h$ ) charges the shaykh al-islam with the task of preserving the religious sciences, and grants him the letter of authority, then he [the shaykh al-islam] should investigate the affairs of the jurists ('ulamā') of [his] dominion. He must keep [the sultan] informed of their level of knowledge and intelligence, their way of teaching, their power of independent reasoning (ijtihād), the ability to issue legal opinions and teach (quvvet-e iftā' ve-tedrīs-e ishān)...."41

\footnotetext{
38 Little is known about educational institutions and the career tracks of jurists in Central Asia and the Mughal Empire in this period.

39 Manz, Power, Politics and Religion, 213; Shiro Ando, "The Shaykh al-Islām as a Timurid Office: A Preliminary Study,” Islamic Studies 33, 2-3 (1994): 253-55.

${ }^{40}$ Repp, Müfti of Istanbul, 73-124.

41 Fazl Allah b. Ruzbahan, Sulūk al-mulūk (Tehran: Intishārāt-i Khvārazmī, 1984), 96.
} 
The shaykh al-islam, in other words, was to preside over what Ibn Ruzbahan envisioned as the khan's learned hierarchy and to operate on his behalf to guarantee that the hierarchy functioned properly. In this capacity, Ibn Ruzbahan maintains, the khan and the shaykh al-islam have authority to inspect and examine the competence and knowledge of their appointed jurists. Ibn Ruzbahan also envisioned a mosaic of state-appointed muftiships, each covering a well-defined territory: "Whenever a mufti is appointed, he is allowed to receive a salary from the treasury (bayt al-māl). If he is appointed [to this office], he must not charge any fee [for his services].... If within the distance of a qasr [roughly forty-eight miles] a post of a learned mufti is vacant, it is an obligation [of the sultan] to appoint a mufti in a town, for otherwise all inhabitants of that place will be sinful...."42 The administrative practice prescribed by Ibn Ruzbahan was apparently implemented, perhaps even before his compilation of this work. By the mid-sixteenth century, there was a dynasty-appointed mufti in Bukhara and probably in other major urban centers across the khanate. ${ }^{43}$ The Özbek appointment of muftis is quite similar to that in the Mughal realms, although not, it seems, identical. There, too, the state appointed muftis, though apparently there was no chief imperial mufti. $^{44}$

Related to the rise of the state-appointed mufti is, of course, the growing importance of his legal opinions (fatwas). As I described earlier regarding the Ottoman case, the rulings of the state-appointed mufti were instrumental in regulating the opinions and doctrines within the Hanafi school of law that members of the Ottoman learned hierarchy were to apply. This seems to have been the reason muftis were appointed in other parts of the eastern Islamic lands, as well. Some of these rulings were collected and circulated throughout the different polities, and some, like the Mughal seventeenthcentury collection al-Fatawa al-'Alamgiriyya, traveled well beyond their boundaries. Although the study of these rulings is still in its embryonic stage, it appears that the rulers played a pivotal role in their production and circulation. This was the case, for example, with the Ottoman collections of the chief imperial muftis' rulings, which were produced fairly systematically and circulated throughout the empire. ${ }^{45}$

42 Ibid., 114-15.

${ }^{43}$ One of these muftis was Muhammad b. Husam al-Dinn al-Quhistani (d. 1554), the author of Jami" al-rumuz. Muhammad b. 'Abd al-Rahman al-Ghazzi, Diwan al-Islam (Beirut: Dar al-Kutub al-'Ilmiyya, 1990), vol. 4: 35-36; 'Abd al-Hayy b. Ahmad b. al-'Imad, Shadharat al-dhahab fi akhbār man dhahab (Beirut: Dar al-Kutub al-'Ilmiyya, 1980-), vol. 8: 300.

${ }^{44}$ Rafat M. Bilgrami, Religious and Quasi-Religious Departments of the Mughal Period (15561707) (New Delhi: Munshiram Manoharlal Publishers, 1984); M. L. Bhatia, Administrative History of Medieval India: A Study of Muslim Jurisprudence under Aurgangzeb (New Delhi: Radha Publications, 1992).

${ }^{45}$ Uriel Heyd, "Some Aspects of the Ottoman Fetvâ," Bulletin of the School of Oriental and African Studies 32 (1969): 35-56; Selma Zecevic, On the Margin of Text, on the Margin of 
Let me dwell on the just-mentioned example of al-Fatawa al-'Alamgiriyya, a collection of rulings compiled in Mughal India during the reign of Aurangzeb (also known as 'Alamgir, r. 1658-1707), and named after him. The collection still awaits thorough study, but it seems that the notion behind this project was to determine what legal opinions the jurists affiliated with the Mughal dynasty were to follow. If al-Fatawa al-'Alamgiriyya is the Mughal equivalent of the collections of the Ottoman chief imperial muftis, then its dynastic sponsorship - which is evident from its title-may have made this collection enforceable throughout the empire's legal system. ${ }^{46}$

Aurangzeb requested that the jurists that he summoned consult the jurisprudential texts he held in his imperial library. Very little is known about the circulation of jurisprudential and other texts throughout the eastern Islamic lands, but let us consider this request more closely. In the Ottoman Empire, the sultan, and later the chief imperial mufti, specified what texts constituted the imperial jurisprudential canon. It is quite possible that Aurangzeb's request was intended to specify what texts made up the distinctive Mughal imperial canon. To be sure, the different imperial canons shared many texts, but an interesting comment from the mid-nineteenth century suggests there were also substantial differences: In his account of the administration of law in colonial India, William H. Morley related that "many works according to the doctrines of Abu Hanifa have been written, and are received as authorities in the Turkish [Ottoman] empire. These I apprehend would be admissible if quoted in our Courts in India where the parties to a suit are of the Hanafi persuasion." 47 In other words, although jurisprudential texts circulated throughout the eastern Islamic lands (and beyond), it seems that the different dynasties succeeded in creating identifiable imperial textual geographies within the Hanafi school of law across the region.

The appointment of muftis by the state/dynasty, the rising importance of their rulings, and the different textual geographies within the Hanafi school

Empire: Geography, Identity, and Fatwá-Text in Ottoman Bosnia (PhD diss., Columbia University, 2007); Burak, Abu Hanifah, 438-43.

${ }^{46}$ Alan N. Guenther, "Hanafī Fiqh in Mughal India: The Fatāwá-i 'Alāmgīrì," in Richard M. Eaton, ed., India's Islamic Traditions, 711-1750 (Oxford: Oxford University Press, 2003), 209-30. As Joseph Schacht pointed out, the title also alludes to similar earlier projects, such as the fourteenth-century al-Fatawa al-Tatarkhaniyya. Joseph Schacht, "On the Title of the Fatāwā al- 'Alamgìriyya," in C. E. Bosworth, ed., Iran and Islam: In Memory of the Late Vladimir Minorsky (Edinburgh: Edinburgh University Press, 1971), 475-78. Al-Fatawa al-'Alamgiriyya, despite the Mughal sponsorship, was widely consulted in other parts of the Hanafi world, especially in the Ottoman Empire (ibid., 475).

${ }^{47}$ Willian H. Morley, The Administration of Justice in British India, Its Past History and Present State: Comprising an Account of the Laws Peculiar to India (London: William \& Norgate, Stevens \& Norton, Lepage \& Co., 1858), 294. 
across the eastern Islamic lands suggest that the Ottoman adoption and development of a specific branch within the Hanafi school was not a unique case. If my interpretation of these examples is correct, it appears that across the eastern Islamic lands, rulers and dynasties sought to regulate in an unprecedented manner the structure of the school of law and the doctrines that the jurists affiliated with them were expected to follow. If so, from the perspective of Islamic legal history, the post-Mongol period was the era of the state madhhab.

\section{THE CHINGGISID HERITAGE}

So far, I have used the term "post-Mongol" quite freely to denote the chronological framework of my inquiry. But the Mongol invasions of the thirteenth century, culminating in the conquest of Baghdad in 1258 and the execution of the 'Abbasid caliph al-Musta'sim, are significant because of the new notions of sovereignty and law that they introduced to the eastern Islamic lands. Of special relevance is the image of Chinggis Khan as a world conqueror who enjoyed a divine mandate to rule and legislate. In this sense, the term "post-Mongol" is intended to draw attention to the ongoing dialoguesdespite their different manifestations over time and space - that sultans, emperors, and dynasties held with their real and imagined Mongol past and Chinggisid heritage. More specifically, I am interested in investigating ways in which different sovereigns throughout this period envisioned and interpreted Chinggis Khan's political-legal legacy and the relationship between this legacy and the pre-Mongol Islamic notions of law. I propose that the adoption and development of an official state madhhab is one result of the dialogues different dynasties held with the Chinggisid heritage, and particularly with the post-Mongol notion of dynastic law.

That many of these dynasties took Chinggis Khan and the law that was associated with him as a historical and legal point of reference, even when they tried to shift the focus to other dynastic ancestors (as did the Timurids, the Ottomans, and the Mughals), ${ }^{48}$ suggests that we are not dealing merely with parallels and similarities, but with, to paraphrase Sanjay Subrahmanyam's words, a "connected legal history." 49 I seek to reconstruct in fairly broad

48 Despite the importance of Timur in their worldview, the Timurids and the Mughals emphasized Timur's and, by extension, their own link to Chinggis Khan and his lineage. On the significance of Timur in Mughal India and Central Asia, see Stephen F. Dale, The Garden of the Eight Paradises: Bābur and the Culture of Empire in Central Asia, Afghanistan and India (14831530) (Leiden: Brill, 2004); Balabanlilar, Imperial Identity; Moin, Millennial Sovereign, 23-55; Ron Sela, The Legendary Biographies of Tamerlane: Islam and Heroic Apocrypha in Central Asia (Cambridge: Cambridge University Press, 2011). On the importance of Chinggis Khan in Central Asia, see Robert D. McChesney, Central Asia: Foundations of Change (Princeton: Darwin Press, 1996), 117-48.

49 Sanjay Subrahmanyam, "Connected Histories: Notes Toward a Reconfiguration of Early Modern Eurasia,” Modern Asian Studies 31 (1997): 735-62. 
strokes some of the historical and discursive connections and dialogues that spanned the different polities of the eastern Islamic lands of the period.

The Chinggisid universalist notion of sovereignty rested on the view that the divine dispensation to rule the world was given to Chinggis Khan and his descendants. Fittingly, Chinggis Khan was considered a divine legislator. Two concepts capture this notion of sovereignty: Chinggisid yasa and the Turkic töre (or törä). The definition of these concepts and the nature of the Mongol yasa have attracted much scholarly attention over the years and are beyond this paper's scope. ${ }^{50}$ Suffice it to say that the Chinggisid yasa was not, apparently, a fixed written legal code, but rather "an evolving body of individual decrees, regulations, and practices that had been instituted or sanctioned by Chinggis Khān..., a kind of unwritten 'constitution.",51

These notions retained their appeal in the centuries after the Mongol empire's demise, even though all of the successor dynasties in the eastern Islamic lands considered themselves Islamic. This self-perception is expressed in different attempts to draw on pre-Mongol Islamic ideals of sovereignty and kingship in combination with Chinggisid political ideals. Yet despite-or, perhaps, because of - the tensions, the rulers of the successor states upheld key Mongol-Chinggisid ideals of law and sovereignty.

The rulers of the successor states, especially when they were not descendants of Chinggis Khan, modified these ideals to varying degrees. For example, members of the ruling and scholarly elites in the Ottoman and the Timurid lands, two of the better-studied polities that emerged in the centuries following the Mongol empire's fourteenth-century demise, were concerned to articulate their respective claims of sovereignty. Although the dynasts of neither polity were descendants of Chinggis Khan, scholars and rulers in these lands maintained an ongoing dialogue with Chinggisid ideals of sovereignty and law. Writing in the early fifteenth century in the Ottoman lands, Tacü'ddin İbrahim b. Hizır Ahmedi (d. 1413) ${ }^{52}$ dedicated several couplets to the Mongol legal heritage:

50 David Ayalon, "The Great Yasa of Chingiz Khān: A Reexamination (Parts A-D)," Studia Islamica 33 (1971): 97-140, 34 (1971): 151-80, 36 (1972): 113-58, 38 (1973): 107-56; David Morgan, "The 'Great' "Yasa" of Chingiz Khān' and Mongol Law in the Ilkhānate," Bulletin of the School of Oriental and African Studies 49, 1 (1986): 163-76; and, Morgan's, "The 'Great Yasa of Chinggis Khān' Revisited," in R. Amitai and M. Biran, eds., Mongols, Turks and Others (Leiden: Brill, 2005), 291-308; Caroline Humphrey and A. Hürelbaatar, "The Term Törü in Mongolian History," in David Sneath, ed., Imperial Statecraft: Political Forms and Techniques of Governance in Inner Asia, Sixth-Twentieth Centuries (Bellingham: Center for East Asian Studies, Western Washington University, 2006): 265-93.

51 Maria E. Stubtelny, Timurids in Transition: Turko-Persian Politics and Acculturation in Medieval Iran (Leiden: Brill, 2007): 16-17.

52 On Ahmedi, see Kemal Silay, "Introduction," in Tacü'ddin İbrahim b. Hizır Ahmedi, History of the Kings of the Ottoman Lineage and Their Holy Raids against the Infidels (Cambridge: Department of Near Eastern Languages and Literatures, Harvard University, 2004), xiii-iv. 
Concerning the justice ( $a d l$ ) of the Mongol Sultans:/ Hear now the explanation of what it was.

They did not mention the fact that/ Chinggis Khan clearly oppressed the people.

They [the Mongol rulers] oppressed them with the law (kânûnıla),/ but they did not paint their hands with blood.

Lawful oppression and confiscation/are amenable to the people as a form of justice. ${ }^{53}$

Ahmedi's couplets may be read as an attempt to appropriate a Mongol discourse of sovereignty (law and justice) in order to praise the Ottoman sultans, "those of just nature, ... [who] were both Muslims and dispensers of justice." The term Ahmedi uses for "law," kanun, was at times employed by Ottoman authors to refer to the Mongol yasa. ${ }^{54}$ In Ahmedi's eyes, though, what distinguished the Ottoman dynasty from its Mongol counterparts was its just dynastic law. Other contemporary sources saw the promulgation of laws (yasa or kanun) as a sign of the sultan's sovereignty. In a work commissioned by the Ottoman sultan Mehmed I's vezir and presented to the sultan in 1414, the author, 'Abdülvasi Çelebi, recounts the succession struggles between the future sultan Mehmed and his brother Musa. In his description of Mehmed's campaign in Thrace, 'Abdülvasi Çelebi states, "Everywhere he went, he made laws (yasağ) for justice." ${ }^{, 5}$ The important point here is that Ahmedi and 'Abdülvasi Çelebi are employing the Mongol-Chinggisid discourse of sovereignty and the notion of dynastic law to assert Ottoman sovereignty, though they do not explicitly refer to a distinctive Ottoman yasa.

The notion of dynastic law, framed in terms of yasa or töre, was already circulating across the eastern Islamic lands. To the east, in the Timurid domains, the descendants of Timur referred to the "törä [or töre] of the Lord of the auspicious conjunction" (törä-i șāhib-qirān $\bar{l}$ ), and to "the triumphant törä." As Maria Subtelny has explained, "[The törä] appears to have overlapped and complemented the Chinggisid yasa, as the formula 'in accordance with the yasa of Chinggis Khān and the törä of His Excellency, Lord of the auspicious conjunction,' which was frequently cited by Timurid chroniclers, indicates." Nevertheless, it appears that in some instances the Timurid törä differed from the Mongol yasa and referred to specific Timurid customs. But much like the Mongol yasa, the Timurid törä was an evolving corpus of regulations, customs, and practices that were introduced by Timur and observed by his descendants and followers. ${ }^{56}$

Similarly, by the fifteenth and the sixteenth centuries members of the Ottoman dynasty were explicitly referring to their own törä. In a correspondence between Mehmet I and Timur's son Shahrukh concerning Ottoman

53 Ahmedi, History of the Kings, 1 (for the Turkish, see p. 25).

${ }^{54}$ Fleischer, Bureaucrat and Intellectual, 284.

${ }^{55}$ Dimitris J. Kastritsis, The Sons of Beyazid: Empire Building and Representation in the Ottoman Civil War of 1402-1413 (Leiden: Brill, 2007), 224; on 'Abdülvasi Çelebi and his work, see pp. 217-20.

56 Subtelny, Timurids in Transition, 16-17. 
succession practices, preserved in Feridun Bey’s (d. 1583) Münşeatü'l-Selatin, the issue of the Ottoman töre is raised:

[Shahrukh to Mehmet I:] As required by the Ottoman law (töre), you have removed from contention all of your brothers. This type of activity between blood brothers is not in accordance with the Mongol (Ilkhānī) traditions (töre).

[Mehmet I's response:] Your advice with regard to brothers is well taken. However, from the very beginnings of the Ottoman state, our forefathers have used the hand of experience to solve their problems. ${ }^{57}$

Although the authenticity of some of the documents in this collection has been questioned over the centuries, it clearly displays the way in which some members of the scholarly elite in the sixteenth century, and probably earlier, perceived the rise of the Ottoman dynastic law and the relationship between the Mongol yasa/töre and the töre of various local dynasties. Shahrukh presents himself as the defender of Chinggisid (Ilkhānī) traditions, while emphasizing the contradiction between these traditions and the Ottoman töre, thus implying a hierarchy between the Mongol yasa/töre and the Ottoman töre (and others). Mehmet I's reply, on the other hand, suggests that by the fifteenth century local dynastic traditions had gained currency at the expense of the more universalist Chinggisid approach. But regardless of the different approaches toward the Chinggisid tradition, the correspondence indicates that the latter still served as a point of reference in the different dynasties' claims of legitimacy. Lastly, the exchange between the two post-Mongol rulers shows that dynasties not only articulated their notions of sovereignty in relation to their (real or imagined) Mongol past, but also negotiated and debated these ideals with their contemporaries, thus partaking in a shared discourse concerning sovereignty and law. ${ }^{58}$

In the sixteenth century, which witnessed the emergence of four major polities - the Ottomans, the Safavids, the Özbeks, and the Mughals - dynastic laws became the predominant norm. Each of the dynasties followed political, legal, and administrative norms they could trace to a real or imagined ancestral origin, whether the early Ottoman sultans, Chinggis Khan, or Timur. These legal principles became the cornerstone in each dynasty's perception of itself vis-à-vis the others. What is more, in the multiethnic and diverse landscapes of these empires, these political-legal traditions enabled the dynasts to instill a sense of imperial coherence and order. ${ }^{59}$

57 Feridun Bey, Münşeatü'l-Selatin (n.p: n.p, 1858), vol. 1: 143-44. The translation appears in Halil Inalcık, "The Ottoman Succession and Its Relation to the Turkish Concept of Sovereignty," in The Middle East and the Balkans under the Ottoman Empire: Essays on Economy and Society (Bloomington: Indiana University Turkish Studies and Turkish Ministry of Culture Joint Series, 1993), 57. On Feridun Bey, see J. H. Mordtmann and V. L. Menage, "Feridun Bey," Encyclopedia of Islam (2d ed.), http://referenceworks.brillonline.com/browse/encyclopaedia-of-islam-2.

58 The famous fifteenth-century Aqquynulu ruler Uzun Hasan also issued his own yasaknāmes and kânûnnāmes in his teritorries. See: Dale, The Muslim Empires of the Ottomans, Safavids, and Mughals (Cambridge: Cambridge University Press, 2010), 82-83.

59 Fleischer, Bureaucrat and Intellectual, 290. 
From the perspective of Islamic legal history, the rise of distinctive dynastic legal traditions provoked debates between members of the ruling elite and judicial circles across the eastern Islamic lands concerning the relationship between these traditions and Islamic law. Fifteenth- and sixteenth-century chronicles, legal treatises, and other sources attest to the tensions and difficulties that the amalgamation of various legal, political, and religious traditions entailed, or at least was thought to entail. As the authors of these chronicles and treatises observed, there were serious contradictions and tensions between the political-legal heritage of Chinggis Khan and certain pre-Mongol perceptions of Islamic law.

These perceived tensions necessitated the delineation of the boundaries of each of these legal corpuses. Since the Mongol invasions, different jurists had condemned the new rulers for not following the shari ' $a$. For instance, the latefourteenth and early-fifteenth-century jurist Ahmad b. Muhammad b. 'Arabshah (d. 1450), one of the most adamant critics of Timur, accused the latter of trying to "extinguish the Light of God and the Pure Faith [of Islam] with the law of Chinggis Khan." According to Ibn 'Arabshah, Timur's adherence to the yasa led Syrian jurists to consider him an infidel. ${ }^{60}$ On the other hand, Timur's son Shahrukh, said to have been a devout Muslim, declared the abrogation of the Mongol yasa in 1441 and "reinstated the shari ' $a$, and had wine from the taverns publicly poured onto the ground."61 Some of Timur's and Shahrukh's descendants in Mughal India also emphasized their commitment to the shari' $a$. The founder of the Mughal dynasty in India, Babur (d. 1530), explained his view of the proper approach in a well-known passage in his memoir: "Previously our ancestors had shown unusual respect for the Chinggisid code (torah). They did not violate this code sitting and rising at councils and courts, at feasts and dinners. [However,] Chinggis Khan's code is not a nass $q \bar{a} t i^{\prime}$ (categorical text) that a person must follow. Whenever one leaves a good custom, it should be followed. If ancestors leave a bad custom, however it is necessary to substitute a good one." ${ }^{62}$ Babur here acknowledges his ancestors' adherence to the Chinggisid heritage, but at the same time downplays its importance, for it is not, in his mind, a divinely ordained law, as opposed to divine revelation. The last sentence may be read as an expression of Babur's urge to correct his ancestors' misconduct.

To the north, in the Özbek domains, contemporary chronicles record similar tensions between the Chinggisid yasa and the shari' $a$. The

${ }^{60}$ Subtelny, Timurids in Transition, 18.

61 Beatrice Forbes Manz, Power, Politics and Religion in Timurid Iran (Cambridge: Cambridge University Press, 2007), 28. On the conversion of the Ilkhāns to Islam and its ideological implications, see Anne F. Broadbridge, Kingship and Ideology in the Islamic and Mongol Worlds (Cambridge: Cambridge University Press, 2008), ch. 3.

${ }_{22}$ Stephen F. Dale, The Garden of the Eight Paradises: Bābur and the Culture of Empire in Central Asia, Afghanistan and India (1483-1530) (Leiden: Brill, 2004), 171. 
early-sixteenth-century jurist and chronicler Ibn Ruzbahan, whom we have already met, mentions participating in a debate in Samarqand concerning inheritance practices. Against the opinions of several leading jurists, the Özbek dynast Shaybani (or Shibani) Khan ruled for a solution that, in Ibn Ruzbahan's and possibly other jurists' eyes, was "incompatible with the shari 'a," for it originated from the Chinggisid yasa. ${ }^{63}$ Sources from the Ottoman lands likewise preserved this distinction between kanun and shari ' $a$ : in the early sixteenth century, the chief imperial mufti had to insist on the implementation of both dynastic law (kanun) and shari ' $a .{ }^{64}$ In the decades after the Ottoman conquest of the Arab lands in 1516-1517, jurists from the empire's Arab provinces accused their colleagues from the empire's core of following the yasa (i.e., kanun), implying that it was incompatible with the shari ' $a .^{65}$

Most studies of these debates have focused on the tensions between the dynastic and Islamic law as two independent discourses. In this article I have departed from this perspective by suggesting that the tensions between dynastic law and the pre-Mongol ideal of Islamic law (as jurists' law), and the debates they produced, offer us important clues as to the circumstances from which emerged the notion of the official state madhhab that was associated with the dynasty. The official, dynastic school of law (or a branch within it) was the response that dynasts and their affiliated jurists developed to cope with the challenges posed by the encounter between the Chinggisid and pre-Mongol Islamic (Sunni) notions of law.

CONCLUSION: SITUATING THE POST-MONGOL PERIOD IN GRAND NARRATIVES OF ISLAMIC LEGAL HISTORY

Despite its importance, the rise of the state madhhab in the post-Mongol period across the eastern Islamic lands has received insufficient attention in the grand narratives of Islamic legal history. In part, this may be attributed to the

${ }^{63}$ Ken'ichi Isogai, "Yasa and Sharī'ah in Early 16th Century Central Asia," L'Heritage timourdie Iran-Asia central-Inde XVe-XVIIIe siècles 3-4 (1997): 91-103.

64 Zenbilli 'Ali Cemali, Fetava, MS Süleymaniye Library (Istanbul), Fatih 2390, 75r.

65 Michael Winter, "Ottoman Qadis in Damascus in the 16th-18th Centuries," in Ron Shaham, ed., Law, Custom, and Statute in the Muslim World: Studies in Honor of Aharon Layish (Leiden: Brill, 2007): 89-90; Reem Meshal, "Antagonistic Sharī'as and the Construction of Orthodoxy in Sixteenth-Century Ottoman Cairo," Journal of Islamic Studies 21, 2: 182-212. On the other hand, it appears that dynasts tried to tap into the Islamic Sunni discourse of legal authority. In his report of the debate between the Özbek khan and the jurists, Ibn Ruzbahan accused the former of exerting his own discretion (performing ijtiha $\bar{d}$ ), although he was not entitled to do so (Isogai, "Yasa and Shari"ah). This is an interesting comment, for it suggests that some jurists used the legal discourse of authority that was central to the organization and regulation of the school of law - namely, independent discretion to interpret revelation, ijtihād, and following/imitation of more knowledgeable authorities, taqlid - to limit the authority of the khan to derive new laws. Interestingly, several decades later, in the Mughal India, the emperor Akbar also employed the Islamic authoritative discourse and claimed the right to derive new laws on the basis of ijtihād (Moin, Millennial Sovereign, 139-40). 
emphasis that most master narratives of Islamic legal history place on the so-called "formative period" of Islamic law, and on nineteenth-century legal reforms. According to this accepted view, as part of a wider set of modernizing reforms, nineteenth-century states increasingly codified Islamic law. This resulted, these grand narratives argue, in a loss of the fluidity and diversity that had characterized the premodern shari ' $a$ from its earliest centuries. In addition to the codification of law, the state appointment of jurists and especially muftis is seen as part of this modernization of Islamic law by the state, which modeled its legal ideals and institutions after "Western" notions of law. In the colonial context, namely that of the Indian subcontinent, colonial administrators are considered the main contributors to the decline in the fluidity and diversity of the "premodern shari " $a . " 66$ In short, these historical narratives take as one of their most important organizing principles the intervention of the state in regulating the content of the law.

I fully agree that state intervention is a critical factor for the periodization of Islamic legal history. Nevertheless, as I have tried to show in this article, the developments of the post-Mongol period problematize central elements of these standard narratives. I have argued that the rise of the state madhhab, along with the development of legal hierarchies and the different states' appointment of muftis, displayed a growing interest on the part of the postMongol dynasties to intervene in regulating the structure of whatever school (or, more precisely, the branch within the school) they adopted and developed. In some cases, as in the Ottoman Empire, sultans and dynasties appear to have been quite successful in obtaining this goal.

This does not mean that there were no major developments in the nineteenth century that justify treating it as a separate period in Islamic legal history. But it is undeniable that intensive state interventions in regulating school of law, and by extension Islamic law, date from much earlier. As far as the nature of the school of law and the right that sovereigns assumed to regulate it are concerned, the narrative I am offering recognizes much greater continuity between (1) the pre- and the post-nineteenth-century periods; and (2) Islamic and non-Islamic governmental practices. To illustrate this continuity, suffice it to consider the following decree, which was issued in Egypt in 1865:

It has been brought to our attention that some John Does issue fatwas related to sharī'ah cases dealt with in the shari' $a$ courts, in the awqaf ministry and particularly in the Supreme Council of Adjudication. It also transpires that the parties who obtain such fatwas believe them to be valid and see them as an authoritative source that would enable them to achieve their goal-ignorant and unaware of the fact that these fatwas have neither value nor significance whatsoever.... This phenomenon causes grave

${ }^{66}$ For example: Muhammad Qasim Zaman, The Ulama in Contemporary Islam: Custodian of Change (Princeton: Princeton University Press, 2002), ch. 1; Wael B. Hallaq, Sharī'ah: Theory, Practice, Transformations (Cambridge: Cambridge University Press, 2009); Chibli Mallat, Introduction to Middle Eastern Law (Oxford: Oxford University Press, 2009). 
problems and great dispute between the parties, and these John Does assume the honorable position of muftis for their own personal profit. ${ }^{67}$

Rudolph Peters, and more recently Liat Kozma, have offered different interpretations of this decree. ${ }^{68}$ While Peters interprets it as the state's attempt to ban those jurists whose knowledge of "shari ' $a$ " was deficient, Kozma reads it as the (modernizing) Egyptian state's attempt to "monopolize and systemize." Moreover, according to Kozma, "It was the notion of regularization itself with which the central authorities were concerned." "69 Both accounts are right to place importance on regulation, but I find Kozma's "regulation for the sake of regulation" argument unconvincing. If I am correct in my interpretation of the post-Mongol legal reality in the eastern Islamic lands (which included Egypt after its sixteenth-century incorporation into the Ottoman Empire), then, much like their Istanbul-based contemporary and earlier colleagues, the jurists, and other actors affiliated with the Egyptian state, wanted to regulate the content of a particular "shari 'a," or more accurately, a particular school of law, which was to be applied within the confines of the state's legal system. Put more simply, the "modernizing" Egyptian state was employing administrative logic and practices that had by that time been in place for centuries.

Similar continuities are discernable in the colonial context of the Indian subcontinent in the late eighteenth and early nineteenth centuries. This is not to minimize the significance of the changes and innovations the British colonial authorities did introduce to the administration of law there, but it does suggest that the British authorities tapped into Mughal notions of sovereignty and law. The Mughal state regulated the doctrines of the Hanafi school and specified, and in fact, codified, which were to be followed. Continuity can be seen, for example, in the emphasis British administrators in early colonial India placed on specific jurisprudential texts considered particularly authoritative under the Mughals. ${ }^{70}$

To conclude, the dominant master narratives of the history of Islamic law in the eastern Islamic lands and their periodization overlook several of the developments I have discussed here. My intention has been to offer a different analytical framework that calls into question a set of dichotomies that have organized many of these narratives: state or dynastic law/jurists' law; modern/premodern; and Western/non-Western. This account of the emergence

\footnotetext{
${ }^{67}$ Cited in Liat Kozma, Policing Egyptian Women: Sex, Law, and Medicine in Khedival Egypt (Syracuse: Syracuse University Press, 2011), 12.

${ }^{68}$ Rudolph Peters, "Muhammad al-'Abbāsī al-Mahdī (d. 1897), Grand Mufti of Egypt, and His al-Fatāwá al-Mahdīyya," İslamic Law and Society 1 (1994): 66-82; Kozma, Policing Egyptian Women, 11-12.

69 Kozma, Policing Egyptian Women, 12.

70 Robert Travers, Ideology and Empire in Eighteenth-Century India: The British Bengal (Cambridge: Cambridge University Press, 2007), 124-25.
} 
of the concept of the state madhhab in the early modern period also modifies our understanding of nineteenth-century legal reforms. This is not to say that post-Mongol legal notions and practices were not invested with new meanings, or further developed or contextualized in new genealogies (such as those of the West, or modernity). In fact, this framework, and particularly its emphasis on continuity, offers an opportunity to examine how different categories and genealogies - Western and non-Western, modern and premodern - intersected and overlapped in the same administrative and legal practice.

Abstract: This article proposes a comparative analytical framework to study changes in Islamic law during the post-Mongol period, particularly the rise of the official school of law (or state madhhab). Taking as my case study the Ottoman adoption of a particular branch within the Sunni Hanafi school of law, I suggest that this adoption marks a new chapter in Islamic legal history. In earlier periods, while rulers appointed judges and thus regulated the adjudication procedures, they did not intervene, at least theoretically, in the structure and doctrine of the schools of law, which remained the relatively autonomous realm of the jurists. The Ottoman adoption of the school, by contrast, was not merely an act of state patronage, since the dynasty played an important role in regulating the school's structure and doctrine. To this end, it employed a set of administrative and institutional practices, such as the development of an imperial learned hierarchy with standardized career and training tracks and the appointment of jurisconsults (muftis). Some of these practices were found in other polities across the eastern Islamic lands in the post-Mongol period, but these similarities have not been treated comparatively in modern historiography. They suggest that the Ottoman case was part of a broader legal culture that spanned several polities across the region. This article outlines a framework that will enable historians of Islamic law to treat these similarities in a more coherent manner. The framework raises key issues in the historiography of Islamic law and its nineteenthcentury modernization. 